\title{
Morphological and ultrastructural changes in the mucus glands of Apis mellifera drones during pupal development and sexual maturation ${ }^{1}$
}

\author{
Lien MOORS $^{\mathrm{a} *}$, Olivier SPAAS ${ }^{\mathrm{a}}$, Gudrun KOENIGER $^{\mathrm{b}}$, Johan BILLEN $^{\mathrm{a}}$ \\ a Zoological Institute, University of Leuven, Naamsestraat 59, 3000 Leuven, Belgium \\ ${ }^{\mathrm{b}}$ Institut fuer Bienenkunde, Karl-von-Frisch-Weg 2, 61440 Oberursel, Germany
}

Received 6 December 2004 - revised 13 January 2005 - accepted 14 January 2005

Published online 1 June 2005

\begin{abstract}
We investigated the morphology and ultrastructure of the mucus glands of Apis mellifera drones, which represent a peculiar type of male accessory gland. The three different parts of the mucus glands (muscle layer, gland epithelium and lumen) change with respect to age in the distal and the proximal parts. The thickness of musculature and gland epithelium is larger at the proximal part than at the distal part, where the diameter of the lumen is larger. The secretory cells of the epithelium reach their maximum activity during the first days of adult life, which results in a maximally filled gland lumen by the age of 6 days. The mucus glands represent a unique situation as they are of mesodermal origin, whereas the majority of exocrine glands are ectodermal.
\end{abstract}

morphology / mucus gland / Apis mellifera / drone

\section{INTRODUCTION}

Social insects are well known for their impressive variety of exocrine glands, the secretions of which play a role in numerous aspects of colony organization (Billen and Morgan, 1998). However, our knowledge of the exocrine system of social Hymenoptera is based largely on studies of the female castes, whereas males clearly have been the neglected gender. In spite of their rather short lives, males perform an extremely important function, as it is only after insemination with their sperm that queens are able to produce female offspring according to the system of haplodiploid sex determination. Also males are equipped with a number of exocrine glands that perform various functions. Examples, among others, include the production of sex pheromones in the man- dibular glands in a number of ant species (Hölldobler and Maschwitz, 1965) and the territorial scent marks from the labial glands of bumblebee males to attract conspecific females for mating (Kullenberg et al., 1970).

The male reproductive apparatus of most insects is equipped with numerous accessory glands of mesodermal or ectodermal origin, which open into the deferent ducts or the ejaculatory duct, respectively. In different groups of insects these glands vary considerably in size, shape, number and embryological origin (Adiyodi and Adiyodi, 1975; Leopold, 1976; Grassé, 1982; Chapman, 1998). The accessory glands produce secretions with a variety of functions, including contribution to the seminal fluid and activation of the spermatozoa (Davey, 1985; Chen, 1984). Dallai et al. (1999) investigated the ultrastructure of the male

\footnotetext{
* Corresponding author: Lien.Moors@bio.kuleuven.ac.be
}

${ }^{1}$ Manuscript editor: Klaus Hartfelder 
accessory glands in the collembolan Allacma fusca. These male accessory glands display the structural organization of class I ectodermal glands as defined by Noirot and Quennedey (1974). In the male accessory glands of Drosophila, two cell types can be identified, with principal or main cells and secondary or pearshaped cells (Bairati, 1968). A comparative study of the male reproductive organs of 51 bee species, but excluding Apis, was provided by Ferreira et al. (2004). Among these, the Meliponini were characterized by the absence of accessory glands. In drones of A. mellifera, the reproductive organs consist of testes, efferent ducts, pre- and post-vesicular deferent ducts, seminal vesicles (with gland cells), a pair of huge mesodermal mucus glands (Snodgrass, 1956; Woyke, 1958a), an ectodermal bulbus gland and a pair of cornua glands (Koeniger et al., 1996; Koeniger and Hänel, 1996).

The paired mucus glands are large, curved sac-like glands of the drones, which represent a peculiar type of male accessory gland by their characteristic production of mucus. Both glands join at their proximal ends and are situated in the posteroventral part of the abdomen (Bishop, 1920). The secretory cells are arranged as a monolayered epithelium and correspond with class-1 in the classification of Noirot and Quennedey $(1974,1991)$. The mucus glands of honeybees play an important role during sperm transfer (Woyke, 1958a; Woyke and Ruttner, 1958; Koeniger et al., 1989; Koeniger and Hänel, 1996). The drone is sexually mature around the 12th day of adult life (Mindt, 1962) and then ready to copulate. The mating occurs high in the air. During copulation, the drone everts his endophallus into the genital opening of the queen (Woyke, 1958a; Koeniger and Koeniger, 1991). When the endophallus is only half everted, sperm is injected into the vagina of the queen. The muscles of the mucus gland contract and mucus is squeezed into the queen only when the endophallus is fully everted (Koeniger, 1984; Ruttner, 1957). Koeniger (1986) supposed that the mucus played an important role to strengthen the connection of the copulating pair in free flight. The drone becomes paralyzed after eversion of half of the endophallus. The firmness of the everted part which is tucked in the queen must be very considerable: it contains the cervix filled with sperm in the vagina while the bulbus is still inside its own secretion filled with mucus. After copulation the drone leaves a mating sign in the abdomen of the queen with mucus as the most prominent component. The secretion of the mucus glands contribute, together with the secretion of the cornua glands, to the visibility of the mating sign (Koeniger, 1991; Koeniger et al., 1996). Contrary to A. mellifera, the drones of Apis florea do not leave a mating sign in the abdomen of the queen. The drones of this species have rudimentary mucus glands and no mucus for a mating sign is produced (Koeniger et al., 1989). The male bumblebee, Bombus terrestris, transfers a mating plug into the queen's sexual tract shortly after sperm transfer. The plug is a sticky secretion of the male accessory glands and contains 4 fatty acids and 1 cyclic peptid (Baer et al., 2000). Baer et al. (2001) found that linoleic acid, one of the 4 fatty acids, is the only substance in the mating plug of bumblebees that inhibits re-mating behavior. In contrast with mating plugs (or signs) in other insects, the bumblebee mating plug is highly efficient and determines single mating (Baer et al., 2001). Based on structure, position and secretion content, it seems that the male accessory glands of bumblebees and the fire ant Solenopsis invicta are homologous (Mikheyev, 2003). The observation that fire ant male accessory glands contain and transfer the same fatty acids as those of bumblebees makes it likely that both serve to inhibit queen re-mating, although the presence of mating plugs may not be enough to guarantee single insemination (Mikheyev, 2003). Zander (1916) showed that the morphogenesis of the male reproductive system of honeybees starts during the larval stage. Honeybee drones pass through a period of maturation after emerging from the brood cell during which they complete the maturation of sperm in their reproductive system and the secretion in the mucus glands. The mucus glands of honeybees undergo substantial change with respect to age. The mucus glands attain full maturity during the first 9 days after emergence and their secretion changes from a fluid to viscous, slightly alkaline mucus (Mindt, 1962).

In this contribution, we report on the morphology and ultrastructure of the mucus glands of Apis mellifera drones of different ages, which is the first ultrastructural study of these glands in bees. 


\section{MATERIALS AND METHODS}

\subsection{Samples}

Drones of Apis mellifera were obtained from hives in Oberursel (Germany). Mucus glands were studied in drones of 12 age categories from pupae (910-12-14 days after brood cell closure) to adult drones (0-2-3-4-5-6-9-12 days after emergence). To obtain the different ages, newly emerged drones were paint-marked and put in natural colonies until they attained the appropriate age. They were then taken from the colony and their mucus glands dissected and fixed in cold $2 \%$ glutaraldehyde, buffered at $\mathrm{pH} 7.3$ with $50 \mathrm{mM} \mathrm{Na}$-cacodylate and $150 \mathrm{mM}$ saccharose. Postfixation was carried out in $2 \%$ osmium tetroxide in the same buffer. After dehydration in a graded acetone series (50\%-70\%-90\%$100 \%$ ), the glands were embedded in Araldite.

\subsection{Microscopy}

Semithin sections $(1 \mu \mathrm{m})$ for light microscopy were made with a Reichert OmU2 microtome and stained with methylene blue-thionin $(1 \%-1 \%)$. The sections were observed with an Olympus BX-51 microscope. Ultrathin sections $(70 \mathrm{~nm})$ were made with a Reichert Ultracut $E$ and double stained with uranyl acetate and lead citrate in an LKB 2168 Ultrostainer. Sections were examined in a Zeiss EM900 electron microscope. Material for scanning microscopy was first dehydrated in a graded ethanol series (30\%-50\%-70\%). Then samples were washed with $70 \%$ ethanol before exposure to dimethoxymethane. Samples were critical point dried using liquid $\mathrm{CO}_{2}$ with a BAL-TEC CPD030 instrument. Finally, material was coated with gold and observed in a JEOL JSM 6360 scanning electron microscope.

\subsection{Measurements}

Measurements were performed with the Olympus DP-Soft 3.2 software on digital photographs of histological sections. We measured the width of the muscle layer and the glandular epithelium and the lumen of the different ages. To work randomly, a hexagon frame was placed on the image, so the hexagon lines could serve as landmarks for measuring. All data are presented as arithmethic means \pm S.D., performed by the statistical program STATISTICA.

\section{RESULTS}

\subsection{Scanning and light microscopy}

Mucus glands are paired and are situated in the posteroventral region of the drone abdo- men. They have a peanut-like appearance and consist of a more narrow distal and a larger proximal part with a constriction in between. The diameter of the distal part is approx. $850 \mu \mathrm{m}$, whereas the diameter of the proximal part is approx. $1100 \mu \mathrm{m}$. The overall length measures approx. $3700 \mu \mathrm{m}$. The seminal vesicles open in the proximal part of the mucus glands. The mucus glands open into the ejaculatory duct, which ends in the bulbus (Fig. 1).

Histological sections showed considerable differences both with respect to age and gland region (proximal versus distal). In 10 day old pupae, a few days prior to eclosion, the epithelial lining has a thickness ranging between $100 \mu \mathrm{m}$ distally and $150 \mu \mathrm{m}$ proximally, while the gland lumen was still empty (Figs. 2A, B). As a result, opposite epithelial folds touch each other. In adult drones, the thickness of the muscle layer and the gland epithelium in the proximal part is larger than in the distal part, whereas the lumen is larger distally than proximally (Fig. 2C). During the first days of adult life, the muscle layer and the glandular epithelium decrease in the distal as well as in the proximal part (Figs. 3A, B). The maximum lumen diameter of approx. $1080 \mu \mathrm{m}$ is more or less reached at an age of 6 days, and then stays constant in both parts (Fig. 3C). The secretion in adult glands changes in appearance from more homogeneously distributed components to an unhomogeneous granular secretion.

\subsection{Ultrastructural characteristics}

In the pupae, the apical cell membrane of the secretory cells is differentiated into an irregular microvillar border. As there is no lumen in the gland, the microvilli of opposite epithelial walls touch each other. Numerous belt desmosomes occur while centrioles are found near the apical border. At the apical region of the gland cells, no cuticle is found (Figs. 4A, B). The cytoplasm of the cells contains mitochondria, Golgi apparatus, microtubules and numerous lipid droplets. The cell membranes are considerably interdigitated, which could strengthen the intercellular contacts (Fig. 4C). RER is abundant in the tubular form (Figs. 4D, E). The basal cell membrane shows invaginations. Underneath the basement membrane and in between the muscle fibres, some tracheoles are found (Fig. 4F). 


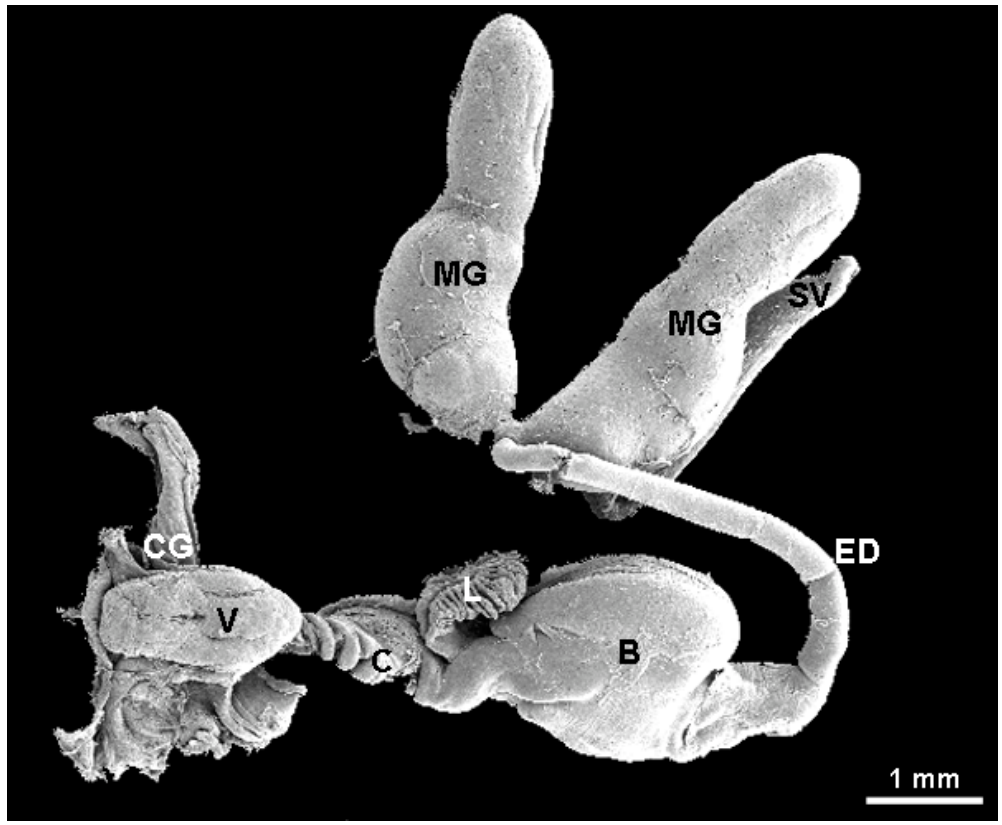

Figure 1. Scanning microscopic image of the male genital system of a 3 day-old A. mellifera drone. MG, mucus gland; SV, seminal vesicle; B, bulbus; C, cervix; L, lobe; CG, cornual gland; V, vestibulum; ED, ejaculatory duct. Testes and deferent ducts were removed.
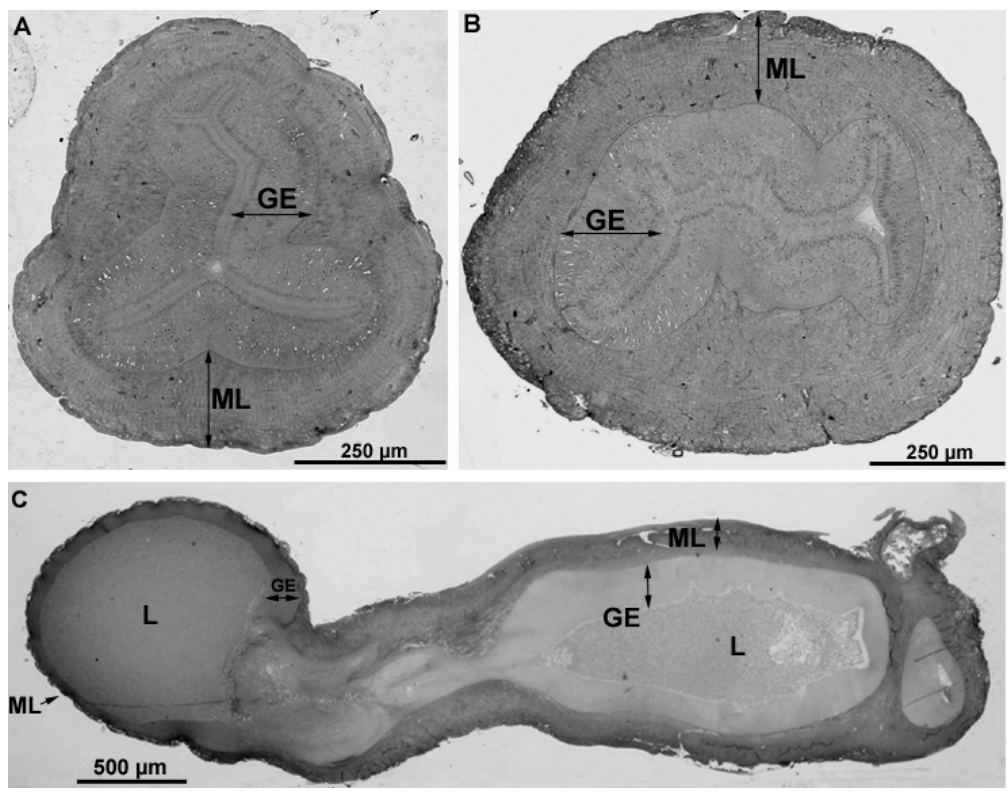

Figure 2. (A, B) Semithin cross section of the mucus gland of a 10 day old pupa (A: distally; B: proximally), (C) Semithin longitudinal section of the mucus gland of a 3 day old adult. ML, muscle layer; GE, gland epithelium; L, lumen. 

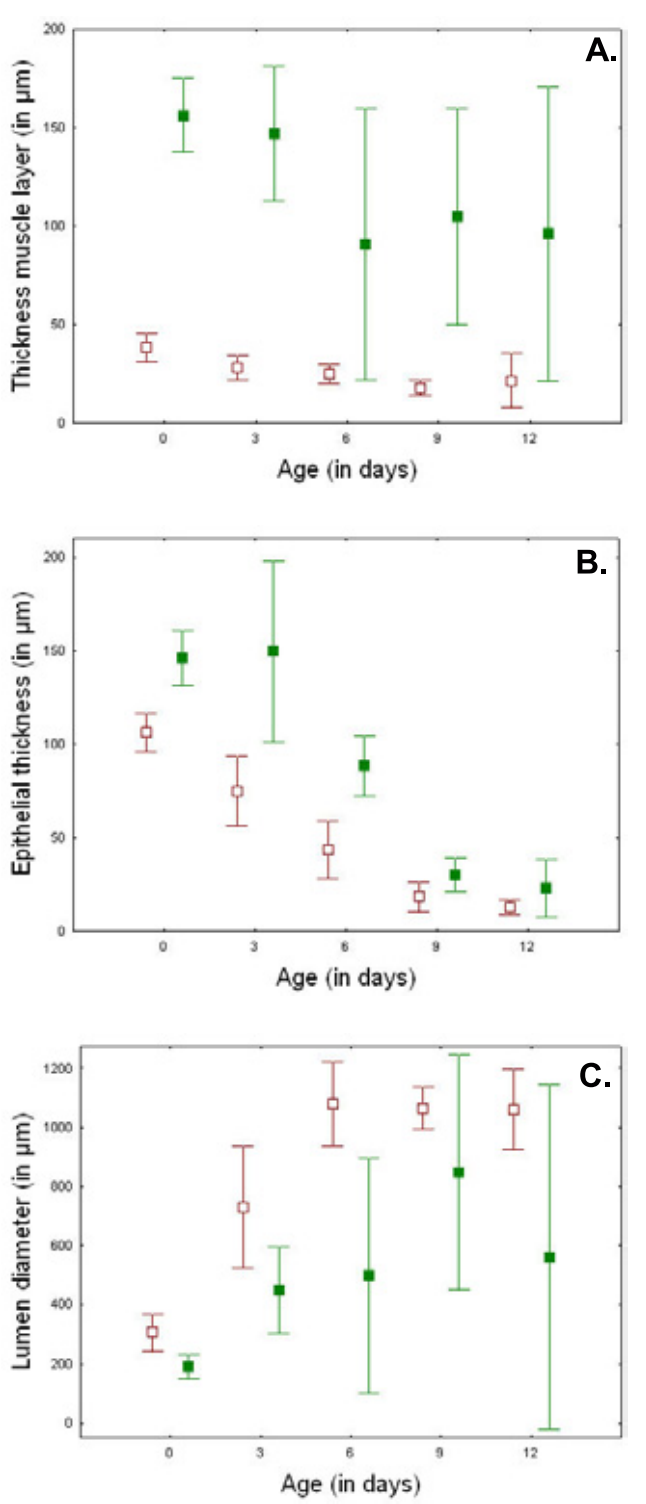

Figure 3. Measurements of the layers of the mucus glands in relation to age, (A) the muscle layer, (B) the gland epithelium, (C) lumen.

$\square$ distal part

- proximal part

In the adult drones, the microvilli border the apical side of the gland cells and are in direct contact with the mucus secretion (Fig. 5A). The lumen of the gland is filled with dark staining secretion (Fig. 5A), which is the result of the high secretory activity of the epithelial cells. At an age of 2 days, the cytoplasm contained an enormous amount of vesicular RER, whereas in the cytoplasm of pupae, the tubular form was more prominent (Fig. 4E). The RER is distributed throughout the cytoplasm (Fig. 5C). The cytoplasm contains numerous mitochondria, as was also the case in pupae. Also Golgi complexes and lipid droplets are present in the cytoplasm of adult cells. The intercellular membranes of adults are less interdigitated than those of pupae (Figs. 4C, 5B). An amorphous basement membrane borders the gland cells (Fig. 5E).

\section{DISCUSSION}

Our measurements show that the musculature of the mucus glands is thinner distally than proximally, the region where the seminal vesicles open in the mucus glands. The muscles of the mucus glands possibly start contracting at the distal part for pushing the mucus towards the duct. The muscles at the proximal part may contract later to press out the rest of the mucus but this needs further investigation. Histophysiological analyses of the secretions in the male accessory glands of Formica ants showed three distinct regions. The distal part secretes proteins, while the proximal part secretes mucopolysaccharides. The transitional part in between secretes both (Jeantet, 1972).

The thick epithelium in the mucus gland of pupae, together with the ultrastructural features of the epithelial cells (omnipresent RER and intracellular secretory droplets), clearly indicate that there is high secretory activity at this stage. Accumulation in the lumen starts more or less at the onset of adult life and reaches its maximum by day 6 . Around this age, the thickness of the epithelium starts to diminish as the glandular cells have fulfilled their secretory function. The epithelial thickness first decreases anteriorly followed by the posterior part. The drone therefore will dispose of the required large amount of mucus by the time he reaches sexual maturity (around day 12, Mindt, 1962). According to Koeniger (1986), the mucus secretion plays a role in the formation of the mating sign after copulation. Bishop (1920) also mentioned a reduction of the glandular epithelium when the drone approaches sexual maturity. 

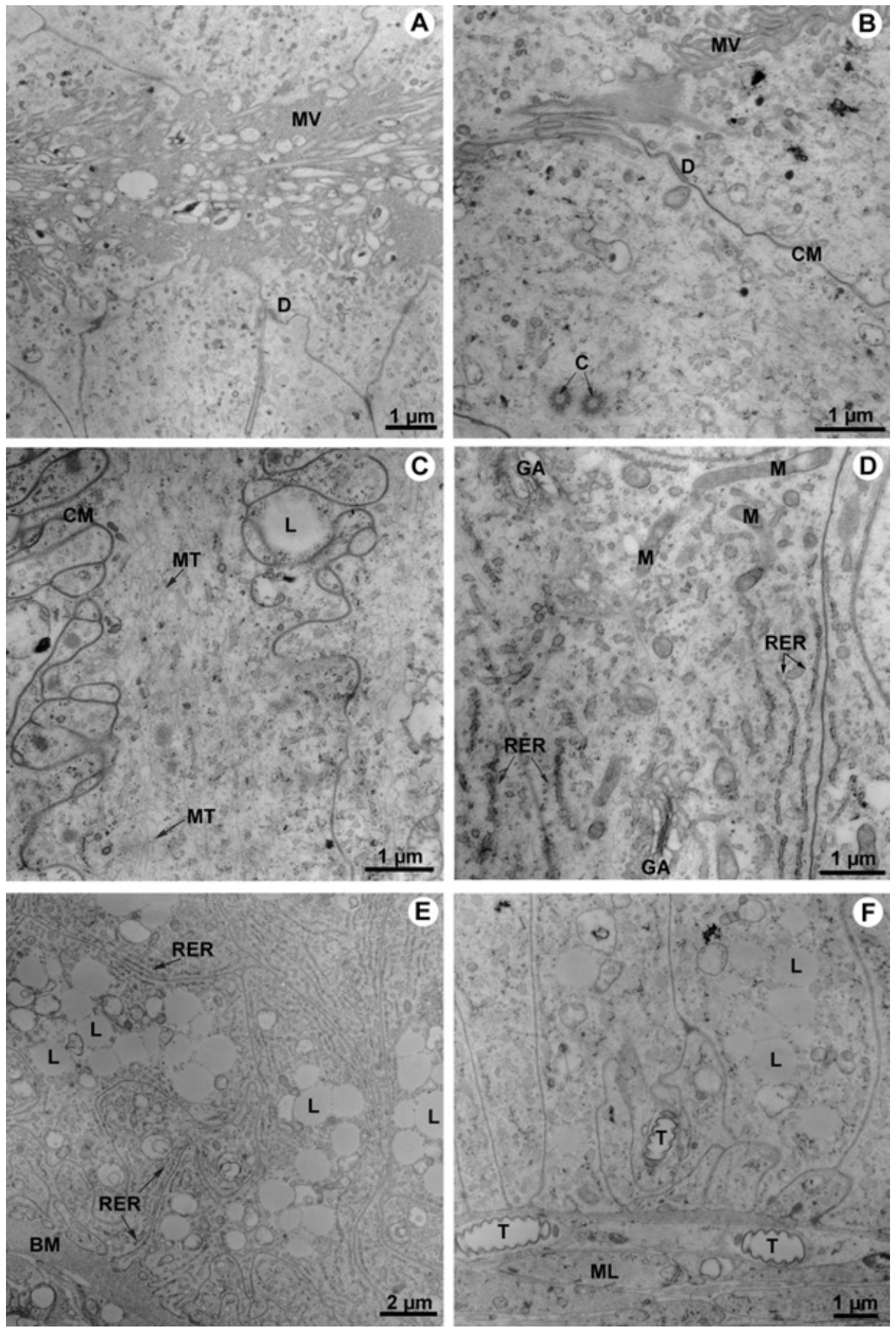

Figure 4. Electron micrographs of the mucus glands of pupae, (A) detail of apical region in a pupa of 14 days, (B) detail of apical region in a pupa of 10 days, (C-E) details of cytoplasm of a pupa of respectively 10, 9 and 12 days, (F) detail of the basal region in a pupa of 14 days. MV, microvilli; D, belt desmosome; $\mathrm{CM}$, cell membrane; $\mathrm{C}$, centriole; M, mitochondria; GA, Golgi apparatus; RER, granular endoplasmic reticulum; MT, microtubuli; L, lipid droplets; BM, basement membrane; T, tracheoles; ML, muscle layer. 

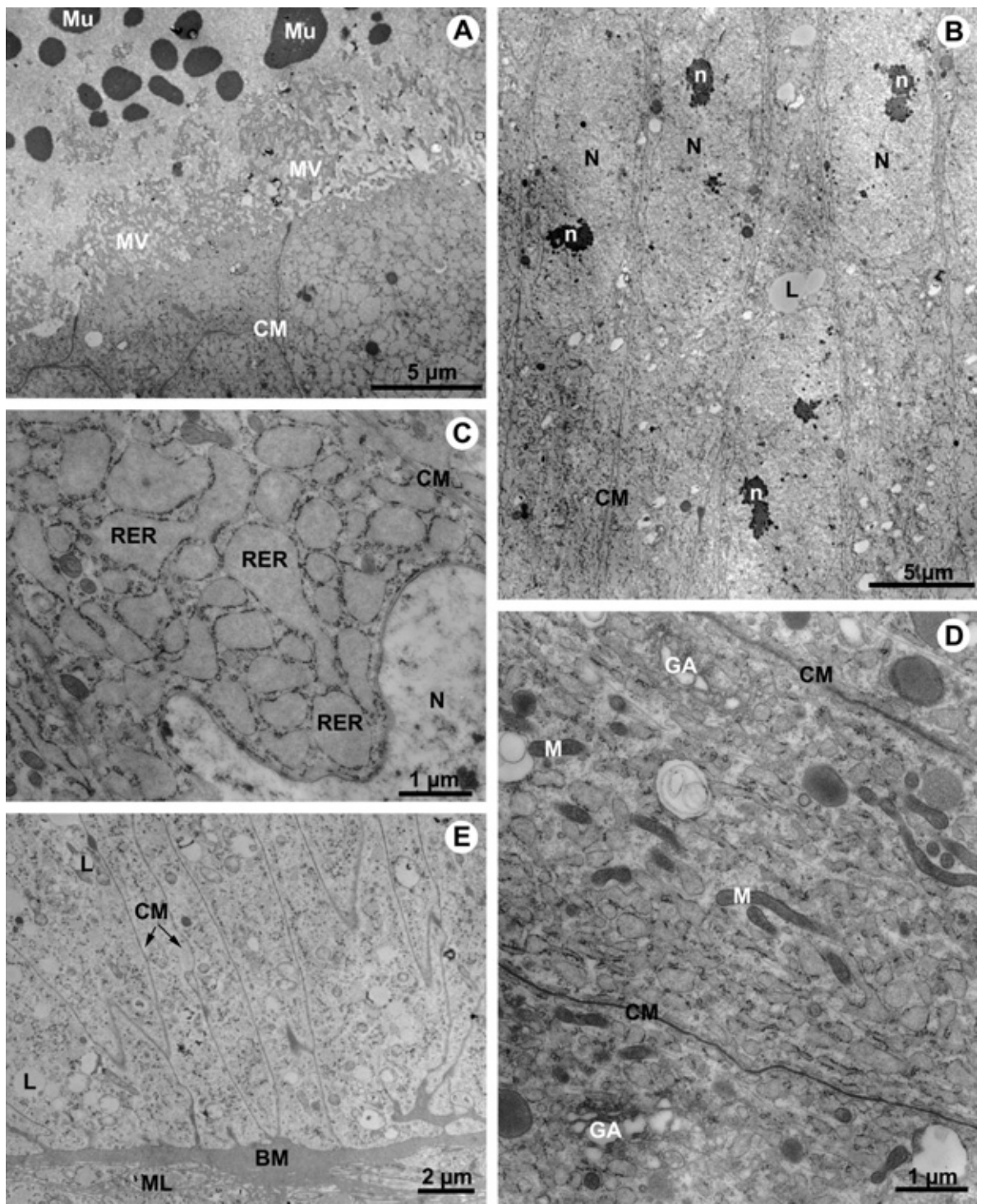

Figure 5. Electron micrographs of the mucus glands of adults, (A) 5 days old, detail of apical region, (B) 0 days old, detail of apical region (C, D) 2 days old, details of cytoplasm and (E) 0 days detail of the basal region. MV, microvilli; $\mathrm{CM}$, cell membrane; Mu, mucus secretion; $\mathrm{N}$, nucleus; $\mathrm{n}$, nucleolus; $\mathrm{L}$, lipid droplets; RER, granular endoplasmic reticulum; M, mitochondria; GA, Golgi apparatus; BM, basement membrane; ML, muscle layer.

The high secretory activity in the mucus gland cells in the newly emerged drone, as reflected by the well developed RER and the epithelial thickness, is also in line with the steep increase of mucus proteins during the first 5 days of the drone's adult life (Colonello and Hartfelder, 2003). The cytoplasm of the accessory glands of the medfly Ceratitis capitata also displays a large amount of RER which is in agreement with the presence of proteins in the secretion (Marchini et al., 2003).

Among the enormous variety of over 100 exocrine glands that can be distinguished among 
the social insects (Billen, 2002), the mucus glands represent a unique situation, as they are of mesodermal rather than ectodermal origin and therefore do not have a cuticular lining of the epithelium. Zander (1916) provided a detailed study on the ontogenesis of the genital apparatus of the honeybee drone. This clearly illustrates how the mucus glands originate as outgrowths from the vas deferens that develop posteriorly, where their distal parts during the early larval stage join the unpaired and ectodermal ejaculatory duct. On the contrary, ectodermal glands develop from epidermal invaginations (instead of mesodermal outgrowths) and, therefore, are always associated with a cuticular component (Quennedey, 1998), which forms a basic element in the classification of insect exocrine glands (Noirot and Quennedey, 1974, 1991). The male accessory glands of Drosophila also have no inner cuticular layer, their origin is also mesodermal (Bairati, 1968). Leopold (1976) and Chapman (1998) mentioned the presence of male accessory glands among the insects with either an ectodermal or a mesodermal origin. In Meliponini the male accessory glands are absent (Kerr, 1948; Ferreira, 1966). Sometimes the role of male accessory glands is taken over by glandular cells of seminal vesicles, vas deferens or ejaculatory duct (Riemann, 1973; Gillot and Friedel, 1976).

Apis has the highest number of matings compared to all other Hymenoptera (Strassmann, 2001). Whereas males generally have large mucus glands, the polyandrous species in fungus-gardening ants have much smaller male accessory glands relative to their seminal vesicles than monandrous species. The extreme reduction of male accessory glands in Attini corresponds with the appearance of polyandry in these ants (Mikheyev, 2004).

We conclude that the elaboration and the accumulation of the mucus gland secretion is particularly established during the first days of adult life and that there is considerable accumulation of material prior to expulsion at the time of mating. Further investigation of the interaction of mucus glands with other parts of the male reproductive apparatus is now in process to gain further insight in this extraordinary and extremely complex copulation apparatus.

\section{ACKNOWLEDGEMENTS}

We are very grateful to Koen Collart and An Vandoren for their help in tissue sectioning, and to Pieter Caris for assistance in scanning microscopy. This research was supported through grant OT/ 2001/24 from the K.U. Leuven Research Fund.

Résumé - Modification de la morphologie et de l'ultrastructure des glandes à mucus des mâles d'Apis mellifera au cours du stade nymphal et de la maturation sexuelle. Bien que les abeilles domestiques (Apis mellifera L.) soient parmi les insectes les plus étudiés, les mâles n'ont reçu que peu d'attention. En dépit de leur courte vie, leur rôle dans la société est de première importance, puisque leur sperme est indispensable pour que la reine produise une descendance femelle. Au cours de la copulation, le mâle retourne partiellement son endophallus dans l'abdomen de la reine, puis le transfert du sperme a lieu au cours de l'accouplement. Lors de l'éversion totale de l'endophallus un signe de fécondation, auquel les glandes à mucus participent, reste attaché. Les glandes ont été étudiées en détail par microscopie optique, électronique et électronique à balayage. L'épaisseur de la couche musculaire et de l'épithélium glandulaire et la taille de la lumière ont été mesurées aux deux extrémités (Figs. 2, 3). Dans les premiers jours de la vie d'adulte, l'activité sécrétrice de l'épithélium glandulaire atteint son maximum, ce qui se manifeste par une lumière totalement agrandie au $6^{\mathrm{e}}$ jour et remplie de mucus (Fig. 3). Cela permet au mâle de disposer de grandes quantités de mucus au moment de la copulation. Du point de vue de l'ultrastructure, nous avons vu des différences dans le réticulum endoplasmique granulaire (RER). Le RER est tubulaire dans le cytoplasme des glandes des nymphes, alors qu'il est vésiculaire chez les adultes (Figs. 4E, 5C). On sait que le RER est impliqué dans la synthèse des protéines, qui augmente au cours de cinq premiers jours de la vie d'adulte. Les glandes à mucus représentent une exception parmi les glandes exocrines, puisqu'elles ont leur origine dans le mésoderme et non dans l'ectoderme, ce qu'illustre l'absence de cuticule (Figs. 4A, B, 5A).

Apis mellifera / mâle / glande à mucus / morphologie

Zusammenfassung - Änderungen in der Morphologie und der Ultrastruktur der Mucusdrüsen von A. mellifera Drohnen während des Puppenstadiums und der sexuellen Reifung. Honigbienen gehören zu den am besten untersuchten Insekten, aber für Drohnen gab es bisher nur begrenztes Interesse. Trotz ihres kurzen Lebens ist ihre Rolle für das Volk sehr wichtig, denn nur mit ihrem Sperma kann die Königin Arbeiterinnen erzeugen. Während der Kopulation evertiert der Drohn seinen Endophallus zunächst nur teilweise in die Königin, 
wobei bereits die Injektion des Spermas erfolgt. Bei der vollständigen Eversion des Endophallus wird ein Begattungszeichen übertragen, an dessen Bildung die Mucusdrüsen beteiligt sind. Mittels Licht- und Elektronenmikroskopie, einschliesslich Rasterelektronenmikroskopie wurden diese Drüsen im Detail untersucht.

Die Dicke der Muskelschicht, des Drüsenepithels und die Lumenweite wurden sowohl im distalen als auch im proximalen Teil gemessen (Abb. 2 und 3). In den ersten Tagen der Adultphase weist das Drüsenepithel die höchste sekretorische Aktivität auf. $\mathrm{Ab}$ dem 6. Tag ist das Lumen vollständig durch die Füllung mit Mucus ausgedehnt (Abb. 3). Dadurch stehen dem Drohn im Moment der Kopulation große Mengen Mucus zur Verfügung.

In der Ultrastruktur konnten wir Unterschiede im granulären endoplasmatischen Reticulum (RER) erkennen. Im Cytoplasma der pupalen Drüsen kommt nur tubuläres RER vor, während es bei adulten Drohnen vesikulär ist (Abb. 4E, 5C). RER ist als wichtiges Strukturelement an der Synthese von Proteinen beteiligt, und die Proteinmenge der Mucusdrüsen steigt in den ersten 5 adulten Lebenstagen stark an.

Die Mucusdrüsen bilden eine Ausnahme unter den exokrinen Drüsen, denn sie sind mesodermalen und nicht ektodermalen Ursprungs, was sich insbesondere im Fehlen einer Cuticula-Auskleidung zeigt (Abb. 4A, B, 5A).

Morphologie / Mucusdrüsen / Apis mellifera / Drohnen

\section{REFERENCES}

Adiyodi K.G., Adiyodi R.G. (1975) Morphology and cytology of the accessory sex glands in invertebrates, Int. Rev. Cytol. 47, 253-398.

Baer B., Maile R., Schmid-Hempel P., Morgan E.D., Jones G.R. (2000) Chemistry of a mating plug in bumblebees, J. Chem. Ecol. 26, 1869-1875.

Baer B., Morgan E.D., Schmid-Hempel P. (2001) A non-specific fatty acid within the bumblebee mating plug prevents females from re-mating, Proc. Natl. Acad. Sci. (USA) 98, 3926-3928.

Bairati A. (1968) Structure and ultrastructure of the male reproductive system in Drosophila melanogaster Meig. 2 . The genital duct and accessory glands, Monit. Zool. Ital. 2, 105-182.

Billen J. (2002) The source of semiochemicals in social insects, in: Proc. XIV Int. Congr. IUSSI, Sapporo, Japan, p. 11.

Billen J., Morgan E.D. (1998) Pheromone communication in social insects sources and secretions, in: Van der Meer R.K., Breed M.D., Winston M.L., Espelie K.E. (Eds.), Pheromone Communication in Social Insects: Ants, Wasps, Bees, and Termites, Westview Press, Boulder, Oxford, pp. 333.
Bishop G.H. (1920) Fertilization in the honeybee: the male sexual organs, their histological structure and physiological functioning, J. Exp. Zool. 31, 225-267.

Chapman R.F. (1998) The insects: structure and function, Cambridge University Press, Cambridge, p. 770.

Chen P.S. (1984) The functional morphology and biochemistry of insect male accessory glands and their secretion, Annu. Rev. Entomol. 29, 233-255.

Colonello N.A., Hartfelder K. (2003) Protein content and pattern during mucus gland maturation and its ecdysteroid control in honeybee drones, Apidologie $34,1-10$.

Dallai R., Frati F., Lupetti P., Fanciulli P. (1999) Ultrastructure of the male accessory glands of Allacma fusca (insecta, Collembola), Tissue \& Cell. 31, 176-184.

Davey K.G. (1985) The male reproductive tract, in: Kerkut G.A., Gilbert L.I. (Eds.), Comprehensive Insect Physiology, Biochemistry and Pharmacology, Vol. I, Pergamon Press, Oxford, pp. 1-14.

Ferreira A. (1966) Contribuição para o estudo da evolução das abelhas (Hymenoptera, Apoidea) aparelho reprodutor masculino, Tese de Doutoramento, Apresentada à Faculdade de Filosofia Ciências e Letras de Rio Claro.

Ferreira A., Abdalla F.C., Kerr W.E., Cruz-Landim C. (2004) Comparative anatomy of the male reproductive internal organs of 51 species of bees, Neotrop. Entomol. 33, 569-576.

Gillot C., Friedel T. (1976) Development of accessory reproductive glands and its control by the corpus allatum in adult male Melanoplus sanguinipes, J. Insect Physiol. 22, 365-372.

Grassé D.G. (1982) Ejaculate esterase-6 and initial sperm use by female Drosophila melanogaster, J. Insect Physiol. 27, 641-650.

Hölldobler B., Maschwitz U. (1965) Der Hochzeitsschwarm der Rossameise Camponotus herculeanus (Hymenoptera, Formicidae), Z. Vgl. Physiol. 50, 551-568.

Jeantet A.-Y. (1972) Recherches histophysiologiques sur le développement post-embryonnaire et le cycle annuel de Formica (Hyménoptère). 3. Données cytophysiologiques sur les glandes annexes males de Formica polyctena Foerst, Ann. Sci. Nat. 14, 285-303.

Kerr W.E., (1948) Estudos sobre o gênero Melipona, Tese de doutoramento, Piracicaba, USP, Brazil.

Koeniger G. (1984) Funktionsmorphologische Befunde bei der Kopulation der Honigbiene (Apis mellifera L.), Apidologie 15, 189-204.

Koeniger G. (1986) Mating sign and multiple mating in the honeybee, Bee World 67, 141-150.

Koeniger G. (1991) Diversity in Apis mating systems, Westview Press, pp. 199-211.

Koeniger G., Hänel H. (1996) The bulbus gland of drones (Apis mellifera L.), Pszcz. Zesz. Nauk. XL, $45-54$. 
Koeniger G., Hänel H., Wissel M., Herth W. (1996) Cornual gland in the honeybee drone (Apis mellifera L.): structure and secretion, Apidologie 27, 145-156.

Koeniger N., Koeniger G. (1991) Evolutionary approach to mating behaviour and drone copulatory organs in Apis, Apidologie 22, 581-590.

Koeniger N., Koeniger G., Wongsiri S. (1989) Mating and sperm transfer in Apis florea, Apidologie 21, 413-418.

Kullenberg B., Bergström G., Ställberg-Stenhagen S (1970) Volatile components of the cephalic marking secretion of male bumble bees, Acta Chem. Scand. 24, 1481-1483.

Leopold R.A. (1976) The role of male accessory glands in insect reproduction, Annu. Rev. Entomol. 21, 199-221.

Marchini D., Del Bene G., Cappelli L., Dallai R. (2003) Ultrastructure of the male reproductive accessory glands in the medfly Ceratitis capitata (Diptera: Tephritidae) and preliminary characterization of their secretions, Arthropod Struct. Dev. $31,313-327$.

Mikheyev A.S. (2003) Evidence for mating plugs in the fire ant, Solenopsis invicta, Insectes Soc. 50, 401-402.

Mikheyev A.S. (2004) Male accessory gland size and the evolutionary transition from single to multiple mating in the fungus-gardening ants, J. Insect Sci. 4, 37, http://www.insectscience.org/4.37/.

Mindt B. (1962) Untersuchungen über das Leben der Drohnen, insbesondere Ernährung und Geschlechtsreife, Z. Bienenforsch. 6, 9-33.

Miyatake T., Chapman T., Partridge L. (1999) Matinginduced inhibition of re-mating in female Mediterranean fruit flies Ceratitis capitata, J. Insect Physiol. 45, 1021-1028.
Noirot C., Quennedey A. (1974) Fine structure of insect epidermal glands, Annu. Rev. Entomol. 19, $61-80$

Noirot C., Quennedey A. (1991) Glands, gland cells, glandular units: some comments on terminology and classification, Ann. Soc. Entomol. Fr. (N.S.) 27, 123-128.

Quennedey A. (1998) Insect epidermal gland cells: ultrastructure and morphogenesis, in: Harrison F.E., Locke M. (Eds.), Microscopic Anatomy of Invertebrates, Wiley-Liss, Vol. 11A, pp. 177-207.

Riemann J.G. (1973) Ultrastructure of the ejaculatory duct region producing the male housefly accessory material, J. Insect Physiol. 19, 213-223.

Ruttner F. (1957) Die Sexualfunktionen der Honigbienen in Dienste ihrer Sozialen Gemeinschaft, Z . Vgl. Physiol. 39, 577-600.

Snodgrass R.E. (1956) Anatomy of the Honey Bee, Comstock Publ. Assoc. Cornell Univ. Press, Ithaca N.Y., p. 343.

Strassmann J. (2001) The rarity of multiple mating by females in the social Hymenoptera, Insectes Soc. $48,1-13$.

Woyke J. (1958a) The histological structure of the reproductive organs of the drone, Poznan Soc. Friends of Sci., Publ. Sect. Agric. Sylvic. 19, 38-

Woyke J. (1958b) The process of mating in the honeybee (Polish with English summary), Pszcz. Zesz. Nauk. II, 1-42.

Woyke J., Ruttner F. (1958) An anatomical study of the mating process in the honeybee, Bee World 39, $3-18$.

Zander E. (1916) Die postembryonale Entwicklung des Geschlechtsapparates der Drohne (Apis mellifica L.), Z. Angew. Entomol. 3, 7-20. 